\title{
Paul's teaching on the use of alcohol and its implications for the church in Nigeria
}

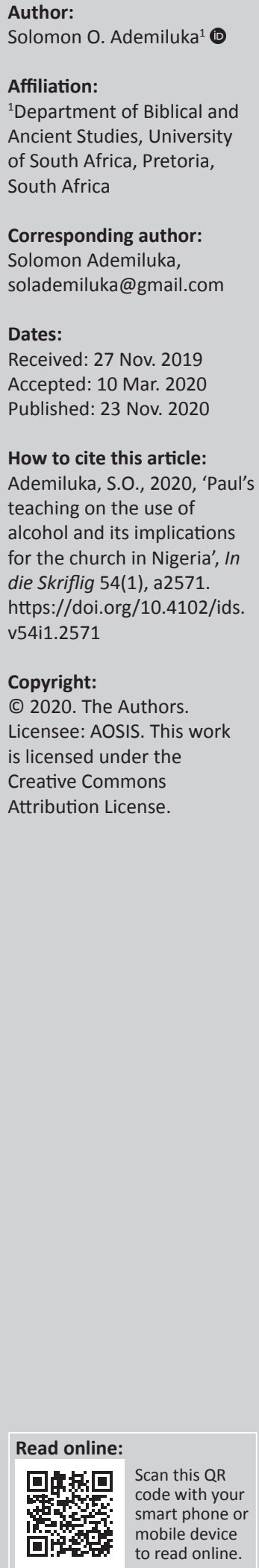

The topic of alcohol consumption is very relevant in contemporary Nigeria not only because alcohol is heavily consumed in the country, but because it is also commonly abused. Relating the issue of alcohol to Nigerian Christians is also significant, because the question of the proper Christian attitude to alcohol is always a public discourse; and whereas most Christians are not knowledgeable on the accurate teaching of the Bible on alcohol consumption, most denominations do not have any faith-based statement on it. Hence, the article examined the implications of Paul's teaching on alcohol for the church in Nigeria regarding a Christian attitude to alcohol consumption. The target groups are the church in Nigeria, and Nigerian Christians who are confused regarding the correct Christian attitude to alcohol consumption. The article employs the exegetical and descriptive methods. It found that the Greek word oinos (wine) in the New Testament (NT) refers to fermented grape juice; this was very commonly used and was usually well diluted with water before drinking, in order to reduce its alcohol content. The article also discovered that Paul did not command total abstinence from alcohol. He only warned Christians in general and church leaders specially against drunkenness. The relevance for Nigerian Christians therefore resides in the context of widespread alcohol abuse, which is a challenge to the church. The article recommends that the church should develop a Bible-based theology in her attitude to alcohol. In line with Paul's teaching, rather than ordering total abstinence, the programme should encourage Christians to avoid drunkenness.

Keywords: oinos; Paul; drunkenness; the church; Nigeria.

\section{Introduction}

Several scholars have studied the subject of alcohol in Nigerian context. Obot (2007) examines the production and consumption of alcohol in Nigeria, Dumbili (2013) the changing patterns of alcohol consumption, and Nelson (2014) studies the attitude of the Pentecostal churches to alcohol drinking, to mention only a few. The topic of alcohol consumption is very relevant in contemporary Nigeria, keeping in mind the fact that the country is currently rated as one of the nations with the heaviest alcohol consumption in the world. Moreover, in Nigeria, the question of the correct Christian attitude to alcohol is always a public discourse, and whereas most Christians are not knowledgeable on the accurate teaching of the Bible on alcohol consumption, the various denominations do not have a common position on the issue. Hence, this article coalesces Paul's teaching on alcohol and examines its implications for the church in Nigeria regarding a Christian attitude to alcohol consumption. The target groups are the church in Nigeria, and Nigerian Christians who are confused on the position of the Bible on alcohol consumption. The work employs the exegetical approach for the study of relevant texts, and the descriptive method for the analysis of Nigerian Christians' attitude towards alcohol consumption and the role of the church. The work begins with an analysis of Nigerian Christians' attitude to alcohol consumption from which it proceeds to the analysis of the nature and use of oinos [wine] in New Testament (NT) times. Next, the article does an exegesis of relevant passages on Paul's teaching regarding wine, and finally assesses the implications of the teaching for the church in Nigeria.

\section{Christian attitude to alcohol consumption in Nigeria}

Nigeria is currently one of the countries with the heaviest alcohol consumption in the world. According to Dumbili (2013:23), a 2004 report by the World Health Organisation (WHO) ranked the country 'among thirty countries with the highest per capita consumption of alcohol globally'. In 2012 Nigeria was the world's second biggest consumer of alcohol after Britain, and it was then reported that beer 'turnover in Nigeria [was] growing faster than its economy' (Alcohol sales surge in Nigeria 2012). In 2017 Nigeria was rated 'the number one in Africa for alcohol consumption' (Helicopter View 2017). In Nigeria, alcohol is not only massively consumed, but 
also commonly abused. Hence, many have pointed out that alcoholism has diverse 'social, health, economic, [and] psychological' effects on abusers and the society at large (Dumbili 2013:27; cf. Nelson 2015:106). According to Bonhoeffer (1971), '[T]he church is the church only when it exists for others [sharing] ... in secular problems of ordinary human life' (cited in Mangayi 2014:135). It is in this regard that the church in Nigeria should relate its witness to the subject of alcohol. Evidence reveals that most Nigerian Christians are not knowledgeable on the accurate teaching of the Bible on alcohol consumption, and unfortunately the various denominations do not have a common position on the issue. Generally, most churches discourage their members from drinking alcohol, but most of them do not have any formal statement of faith concerning their attitude to alcohol. 'The subject is rarely taken up in regular Bible studies or developed as catechism. It may be mentioned occasionally in sermons, but mostly in passing' (Nelson 2014:121). The Roman Catholic Church is among the few that have some stated position on alcohol. As contained in its catechism:

The virtue of temperance disposes us to avoid every kind of excess: the abuse of food, alcohol, tobacco, or medicine. Those incur grave guilt who by drunkenness ... endanger their own and others' safety. (Udodiong 2018)

This is also the stand of the Anglicans and the Lutherans on alcohol consumption (Udodiong 2018). Most of the Pentecostal and Neo-Pentecostal churches espouse 'a prohibitionist view of alcohol, as part of a rigid insistence on a strict moral ideology' (Nelson 2014:119). Nelson (2014) further explains:

[Pentecostal Churches] assume that the Bible condemns the use of alcohol in any manner. In making a case for total abstinence from alcohol, most Pentecostal Christians focus on passages of the Bible that condemn or show the results of alcohol misuse but neglect those passages that show that there can be a proper, moderate use (p. 121).

Nevertheless, Christians themselves remain divided over whether the Bible allows Christians to drink alcohol or not. According to Servant (2019):

\footnotetext{
... within the body of Christ ... there is a wide spectrum of opinion on the proper answer to [this] question. There are some who say Christians should never drink alcohol ... and there are those that say there's nothing wrong with alcohol, as long as you don't get drunk.
}

A similar result was obtained in a kind of opinion poll conducted in 2014 by The Guardian among some Nigerian Christians. While '[s]ome who spoke were against alcoholic consumption, others encouraged moderation' (Irekamba \& Adunwoke 2014). Thus, the two major sides on the controversy are clear, namely those that forbid drinking totally, and those who argue for moderate drinking. The first group is already represented in some Pentecostal Christians, as seen above in Nelson (2014). An example of this position is seen in the attitude of the General Overseer of the Redeemed Christian Church of God (RCCG), Pastor Enoch Adeboye. In forbidding alcohol drinking, he says, '[Y]ou simply have to look at the fruit of an action before you know whether it is good or not' (Akpu 2016). To buttress his position, Adeboye cited Proverbs 20:1 which describes wine as a mocker, and Genesis 19:30-38 where Lot's daughters were able to seduce their father to have sex with them because he was drunk (Akpu 2016). The Lagos-based Pentecostal pastor, Lazarus Muoka, goes a little further, decreeing that Christians must not even sell or serve alcohol. They must 'not work in breweries and not work in any hotel where such things take place' (Adedipe 2017). On the other hand, Christians who argue for moderate drinking often cite some Bible passages to support their claim, particularly John 2:1-10 where it is recorded that Jesus turned water into wine. Some even say 'that Christians can drink because ... Jesus drank wine' (Pope 2011; cf. Udodiong 2018). In response to Pastor Muoka who says Christians must abstain from selling or serving alcohol, his critics also cite Jesus' miracle at Cana and 1 Timothy 5:23 where Paul instructs Timothy to use wine for his ailments (Adedipe 2017).

Although not all interpreters agree on the connotation of the word oinos as used in the NT, many believe it indicates an alcoholic drink. Hence, before examining Paul's teaching on alcohol, in the following section the article studies the Greek term oinos as used in NT times.

\section{The nature and use of wine (oinos) in New Testament times}

Oinos is mentioned in several passages in the Gospels, but of particular relevance for this work are Jesus' parable of 'new wine in new skins' (Mt 9:17; cf. Mk 2:22; Lk 5:37-39) and his miracle of turning water into wine (Jn 2:1-10). These passages are important because they furnish significant information on the connotation of oinos as used in the NT. In the former passage, as part of his response to the Pharisees who accused Jesus of eating with tax collectors, he says:

$[N]$ either is new wine put into old wineskins; if it is, the skins burst, and the wine is spilled, and the skins are destroyed; but new wine is put into fresh wineskins, and so both are preserved. (Revised Standard Version [RSV])

According to Patton (n.d.:64), the explanation of this parable, usually given by interpreters who believe that oinos always indicates alcohol in the NT, is that 'new [skin] bags were used in order to resist the expansive force of the carbonic acid gas generated by fermentation' (cf. also Kerr 1968:14). This explanation, however, runs contrary to the well-known custom in Jesus' days concerning wine preservation. Patton (n.d.:63) explains that in this custom, new wine (oinos neos), 'the juice fresh from the press', was not put into old bottles, that is, goatskins, otherwise the wine would spoil and the bags punctured. Hence, new wine must be put into new bottles so that both are preserved. Explaining further, Patton (n.d.) states:

[F]ermentation depends upon the access of air to the grape-juice

... The new bottles or skins, not that their strength might resist the force of fermentation, but, being clean ... and closely tied and 
sealed, so as to exclude the air, the wine would be preserved in the same state in which it was when put into those skins. [T] he old [skins] would not suit, not because they were weak, but because they would have portions of the albuminous matter or yeast adhering to the sides. This, having absorbed oxygen from the air, would become active fermenting matter, and would communicate it to the entire mass. (pp. 63-64)

\section{As Kerr (1968) puts it:}

It was imperative that new, perfectly clean skins be used, as any dregs left clinging to the inside of the old skins would soon set up a ferment sufficient to ruin the 'new wine' being poured in, and burst the bottles. (p. 14)

Kerr observes that 'new wine' in this passage 'is the translation of the Greek words "oinos neon" which is equivalent to the Hebrew "tiros $[h]$ " indicating that the fresh juice of the grapes is being indicated' (p. 14). Thus, according to Patton, Matthew 9:17 'goes a great way toward establishing the fact that Christ and the people of Palestine recognised the existence of two kinds of wine - the fermented and the unfermented' (p. 65). Similarly, Bacchiocchi (2001) opines that Matthew 9:17 is one of 'the indications of the [New Testament] usage of oinos as unfermented grape juice' (p. 56). Nonetheless, as indicated by the Jewish custom just explained, the difference between fermented and unfermented wine might not be all that pronounced. New wine was put into new wineskins to prevent air from infusing into the wine and get it fermented. This implies that fermented wine is wine which has absorbed air. Because wine must be opened before it is consumed, and because opening it allows air into it, one would be correct to say that all wine is fermented to some extent at the point of consumption. Keener (1993) buttresses this point when he says, 'Soon after the grape vintage all wine would contain some alcohol [since] neither refrigeration nor hermetic sealing existed' (p. 268). But it is very pertinent to note, as Keener (1993) clarifies, that:

... the alcohol level of the wine was not increased artificially [because] distillation was not in use; rather, the wine was watered down with two to three parts water to one part [of] wine. (p. 268)

As discussed more fully at the end of this section, this clarification is very crucial for the understanding of the concept of wine in the NT; it might explain why most references to wine denote alcohol. The same clarification may explain why in Acts 2:13 'new wine' is conceived as alcohol (cf. v. 15 where the apostles are accused of being drunk) even when 'new wine' is the translation of the Greek gleukos, and not oinos neos. Ellicott's commentary states that gleukos 'was sometimes used ... for the unfermented grape-juice' (Bible Hub 2019a). That oinos and gleukos are sometimes used synonymously, is also indicated in the Septuagint (LXX) of Job 32:19 where, instead of oinos, 'yayin [wine] is rendered gleukos, which is the common Greek word for newly pressed grape juice' (Bacchiocchi 2001:48). In this way, as Brown (2015) plausibly notes, Acts 2:13-15 shows that even 'new wine' may also indicate alcohol in the NT.
In the bid to determine the nature of oinos as used in John 2 where Jesus turned water into wine, scholarly discourse surrounds the meanings of the term good wine and the Greek word methustho-sin (v. 10). After tasting the waterturned wine, the archi triklinos [the steward of the banquet] exclaimed, 'Every man serves the good wine first; and when men have drunk freely, then the poor wine; but you have kept the good wine until now' (RSV). On account of this statement, interpreters who hold the view that oinos in the NT exclusively means fermented wine, maintain that Jesus did not only produce abundant alcohol at the wedding but both he and his disciples partook of it (e.g. Gentry 1986:108). Also arguing from the perspective of 'good wine', Geisler (1982) states:

It is false to say that Jesus made unfermented wine. As a matter of fact, He made wine that tasted so good the people at the wedding feast in Cana said it was better than the wine they had just drunk. (quoted in Bacchiocchi 2001:113)

In the same vein, Gentry (1986:54) claims that Jesus 'miraculously manufactured a high quality wine at Cana'. Also considering the term good wine, Kou (2015:12) states that the fact that 'the wine was alcoholic can easily be seen from ... the saying of the master of the feast'. In his own view and concerning the word methustho-sin, 'good wine' is one which causes inebriation to some extent. Therefore, Kou takes methustho-sin to mean 'to be drunk'. In the same vein, Ellis (1883) had seen in this verb an 'incontestable proof of the alcoholic nature of the wine produced by Christ' ... [ $t]$ he word methusko [like methuo'] in Greek signifies 'to make drunk', 'to intoxicate'; in the passive 'to be drunk' (Bacchiocchi 2001:119).

On the contrary, there are others who hold vehemently that the oinos produced by Jesus at Cana could not be alcohol. According to Bacchiocchi (2001:115), the claim that the wine Jesus made was alcoholic, arises from the assumption that the word oinos always means alcoholic wine. As earlier seen, Bacchiocchi asserts that the word oinos could refer to both fermented and unfermented wine. Also taking the generic connotation of 'wine' as his premise, Patton (n.d.:71) opines that 'it is begging the whole question to assert that [the wine which Jesus made] was intoxicating'. These scholars also have a different view of the concept of good wine in John 2:10. Contrary to the alcoholic interpretation, Bacchiocchi (2001:116) says that the assumption that good wine means it is high in alcoholic content, is based on 'twentieth-century tastes', and therefore false. Barnes (1875) also warned against using the term 'good wine to denote that it is good in proportion to its strength and its power to intoxicate [because] no such sense is to be attached to the word here' (Bacchiocchi 2001:116). Quoting Pliny (1960), Bacchiocchi reiterated that 'in the Roman world of New Testament times, the best wines were those whose alcoholic potency had been removed by boiling or filtration'. Supporting the non-alcoholic interpretation of the wine, which Jesus produced at Cana, La Vista Church of Christ (2016) also asserts that: 
[I]n a society that lacked refrigeration, fresh juice was prized over vinegary or fermented juice. At best the governor's statement [in John 2:10] does not prove the oinos was alcoholic.

These interpreters therefore conclude that 'good wine' in this passage means non-alcoholic drink.

The non-alcoholic view of the wine Jesus made, also reject the argument that the verb methuo ${ }^{-}$in John 2:10 means only 'to be drunk', which would attest to the fact that the wine, provided by Jesus, must also have been intoxicating just like the good wine usually served at the beginning of a feast. Bacchiocchi (2001:119) notes that the Greek verb methuo ${ }^{-}$or methusko-'can mean "to drink freely" without any implication of intoxication'. The scholar states further, 'Methuo ... denotes in general to drink wine or strong drink more freely than usual, ... whether to drunkenness or not' (p. 119). He believes that the verb is used in John 2:10 in the sense of satiation. 'It refers simply to the large quantity of wine generally consumed at a feast, without any reference to intoxicating effects' (Bacchiocchi 2001:120). Similarly, La Vista Church of Christ (2016) is of the view that methuo' could not mean 'to be drunk' here, because it was the duty of the governor of the feast to prevent drunkenness. From the moral perspective, another reason for rejecting 'the assumption that "the good wine" produced by Christ was high in alcoholic content, is the negative reflection such an assumption casts upon the wisdom of the Son of God' (Bacchiocchi 2001:118). If Jesus miraculously produced about 180 gallons (Jn 2:6) of intoxicating wine for people to drink at a wedding feast, his moral uprightness is in question (Bacchiocchi 2001:118). Patton (n.d.:72) asserts that such a miracle would be 'derogatory to the character of Christ and the teachings of the Bible'.

However, the argument that the drink which Jesus produced at Cana was not fermented, may have arisen from an inadequate understanding of the term good wine as used in the NT. The meaning of this phrase in practical terms can be deduced from the custom of wine preservation in Matthew 9:17 earlier discussed. As seen in this custom, new wine was put into new wineskins, not the old, because the old skins usually contained dregs clinging to it on the inside which would absorb air and ruin the new wine being poured into it by getting it fermented. That means that this custom was meant to prevent fermentation. In other words, fermented wine was considered as spoilt wine, and unfermented wine invariably as 'good wine'. Nevertheless, as earlier mentioned it was practically impossible to get wine that was totally alcohol-free, because soon after vintage all wine would contain some amount of alcohol, because there was neither refrigeration nor hermetic sealing to prevent fermentation. But to reduce the alcohol content, there was the practice of maximally diluting it with water. The 'good wine' then, was a mixture of water and wine which inevitably contained a certain amount of alcohol. This was the nature of the wine Jesus produced, that is, wine mixed with water (Jn 2:7-9). (The nature of oinos as drunk in NT times, is discussed in greater detail below).
Nevertheless, the narrator most probably used methustho'sin in John 2:10 to mean 'to drink freely', not 'to get drunk'. As already seen, some scholars define methuo- as 'to be drunk', or 'drunken with wine', but some others note that the verb can also mean 'to drink a lot' (Friberg Lexicon in Koehler, Baumgartner \& Stamm 1994-2000). The UBS Lexicon (in Koehler et al. 1994-2000) suggests that in John 2:10, the term most likely means 'to drink freely'. Moreover, drunkenness seems not to be part of Jewish celebrations, unlike Greek parties where 'drunkenness was induced through less dilution [of wine] or the addition of herbal toxins' (Keener 1993:268). According to Keener (1993:268), among the Jews the rabbis disapproved of such practices. It is also noteworthy that at occasions such as at Cana, it was the duty of the archi triklinos not only to ensure adequate dilution of wine, but also 'to regulate the distribution of wine to prevent excess that would ruin the party' (Keener 1993:268). Hence, as Keener (1993:268) rightly affirms, 'that drunkenness is part of the celebration at Cana is unlikely'. The nature of 'good wine' also answers the question of moral implication. As discussed above and will be seen fully below, it was wine that was diluted to make it mild by reducing the alcohol content, and thus not intended to intoxicate. Evidence from the NT indicates that Jesus was not opposed to drinking wine in this state. Highly instructive in this regard is his saying in Matthew 11:18-19, where Jesus confirms that he was a drinker of wine: 'The Son of man came eating and drinking ...' (RSV). Lawrence (2010) opines on account of this passage that 'It is fair to say that ... moderate use [of wine] was acceptable to Jesus'. Thus, oinos in John 2:10, as in Matthew 9:17, indicates an alcoholic drink.

Nonetheless, some scholars argue intensely against the alcoholic interpretation of oinos in the NT. Citing instances from Greek literary texts, Bacchiocchi (2001:47) rejects what he calls 'the narrow definition of oinos as denoting only fermented wine'. According to him, Aristotle (384-322 BCE), in his book Metereologica, made reference to gleukos as grape juice which solidified when boiled, and which, 'though called wine [oinos], it has not the effect of wine for ... it does not intoxicate like ordinary wine' ${ }^{\prime}$ (Bacchiocchi 2001:47). ${ }^{1}$ Bacchiocchi also finds evidence in the LXX for the dual meanings of oinos. Relying on Gordon (1947), he opines that, in the LXX, the Hebrew tirosh is rendered oinos at least 33 times without the adjective neos [new]. 'Oinos without qualification, then, can easily mean unfermented wine in the New Testament ${ }^{2}$ (Gordon, quoted in Bacchiocchi 2001:48). Bacchiocchi (2001), therefore, concludes that samples:

[F]rom both secular and religious authors, make it abundantly clear that the Greek word oinos ... was used as a generic term to refer either to fermented or unfermented grape juice. (p. 48)

Kerr (1968:14) also suggests that the nature of the wines used in Palestine by the time of Jesus, would 'approximate to those in Greece and Rome'. Bacchiocchi (2001:56) identifies the usage of oinos as unfermented grape juice in the NT in 1.It will be recalled that in Acts $2: 15$ gleukos is conceived as intoxicating.

2.This is contrary to the general believe that oinos means fermented wine in the NT, as discussed above. 
Matthew 9:17, already examined and in Revelation 6:6. According to him, in the latter passage, oinos is used in the generic sense in the warning against destroying 'the oil and the wine', which is a reference to the solid fruits, oinos thereby denoting 'the actual fruit [i.e.] the grape'. Bacchiocchi may be correct that oinos in Revelation 6:6 indicates solid fruits of the grape, but in that case, this text is irrelevant in the argument on the nature of wine as grape juice. Thus, literary evidence from outside the NT may prove that oinos had the connotation of fermented and unfermented wine in the NT world, but evidence within the NT itself, tends to indicate that it was conceived as fermented grape juice, that is, alcohol. It is possible that in view of Matthew 9:17 (\& pars.), oinon neon [new wine] was a familiar term, but the witness of Acts 2:1315 makes it doubtful if it was ever conceived as non-alcoholic. Hence, ' $[i] \mathrm{t}$ is widely believed that ... in Biblical Greek the word oinos ... meant exclusively fermented grape juice' (Gentry 1986, cited in Bacchiocchi 2001:46). Relying on several English-Greek lexica, Gentry concluded that 'classical Greek [clearly] used oinos as a functional equivalent for fermented juice; no major New Testament lexicon disputes the fermented character of oinos' (cited in Bacchiocchi 2001:46).

To have adequate knowledge of what oinos really meant in NT times, one needs necessary information on the state in which wine was drunk at that time. In this regard, the information provided by Professor Robert Stein (NT), is highly useful. According to Stein (n.d.), in ancient times wine was usually stored in large pointed jugs known as amphorae, and whenever it was to be drunk, it was poured from there into large bowls called kraters and mixed with water, as earlier hinted by Keener (1993:268). To drink the wine, it was filled from the kraters into cups or kylix. Stein (n.d.) emphasises that:

$[B]$ efore wine was drunk it was mixed with water [though $[t]$ he ratio of water to wine varied. Homer (Odyssey IX, 208 f.) mentions a ratio of 20 to 1 , twenty parts water to one part [of] wine. Pliny (Natural History XIV, vi, 54) mentions a ratio of eight parts water to one part $[o f]$ wine. Sometimes the ratio goes down to 1 to 1 (and even lower), but ... such a mixture is referred to as 'strong wine'. Drinking wine unmixed, on the other hand, was looked upon as a 'Scythian' or barbarian custom.

Wine was therefore always thought of as a mixed drink. Stein quotes Plutarch (Symposiacs III, ix) as saying: 'We call a mixture "wine," although the larger of the component parts is water.' As already noted above, diluting wine with water was considered so important that it was the view of the ancients that only 'barbarians drank it unmixed, and a mixture of wine and water of equal parts was seen as "strong drink" and frowned upon' (Stein n.d.). It is important to note that this practice was popular among the Jews. Stein (n.d.) refers to 'the 1901 Jewish Encyclopedia (Vol. 12, p. 533)' (online) which confirms that diluting wine with water was a well-known practice in the rabbinic period. Also, the Talmud (c. 200 BCE to CE 200) contains several tractates in which the mixture of water and wine is discussed. According to Stein (n.d.):
One tractate (Shabbath 77a) states that wine that does not carry three parts of water well is not wine. The normal mixture is said to consist of two parts water to one part wine. In a most important reference (Pesahim 108b) it is stated that the four cups every Jew was to drink during the Passover ritual were to be mixed in a ratio of three parts water to one part wine. From this we can conclude with a fair degree of certainty that the fruit of the vine used at the institution of the Lord's Supper was a mixture of three parts water to one part wine.

Stein (n.d.) also makes reference to II Maccabees 15:39 (c. 60 $\mathrm{BCE}$ ) which states that 'It is harmful to drink wine alone, or again, to drink water alone, while wine mixed with water is sweet and delicious and enhances one's enjoyment.' The writings of the early church fathers also make it clear that 'wine' means wine mixed with water. Stein finds evidence for this in Justin Martyr's (c. CE 150) writing (Apology 1, 67, 5) in which he describes the Lord's Supper as involving bread, wine and water.

It is clear from this detailed information that in NT times, oinos was 'the main alcoholic substance' (Lawrence 2010), and that it was usually maximally diluted with water before it was drunk. According to Lawrence (2010), it was 'sometimes watered as a substitute for plain drinking water'. Hence, any strict differentiation between fermented and unfermented wine in NT times becomes unrealistic. As Edwards (2019) puts it, 'To insist on a distinction between intoxicating and unfermented wine [in the NT] is a case of unjustifiable special pleading.' It is against this background of the meaning of oinos that this article examines Paul's teaching on alcohol in the following section.

\section{Paul's teaching on alcohol}

Paul's teaching agrees with the concept of oinos as given above in that it recognises that wine was commonly used in the NT. But it also seems to indicate that it was most probably abused. In this section, the teaching of the apostle on this subject is studied from two major perspectives, namely his warnings on wine in relation to Christian behaviour, and in relation to church leaders. In Ephesians 5:18, Paul admonishes his audience not to be drunk (methuskesthe) with wine because that is immoral; instead they should be filled with the spirit of God. Commenting on this verse, Adam Clarke (in StudyLight.org 2019) suggests that the root methuo $^{-}$may have derived from the pagan practices in the Bacchanalian mysteries in which the votaries of the god Bacchus got drunk and ran into all manner of excesses. When the votaries:

$[H]$ ad offered their sacrifices they indulged themselves in drunkenness and ran into all kinds of extravagance. [It is therefore] probable that methuo ${ }^{-}$is derived from meta, after, and thuo ${ }^{-}$, to sacrifice.

This suggestion corresponds to Keener's (1993) view, that the ancients believed that drunkenness could produce a sort of inspiration or possession by Dionysus, god of wine. Perhaps this association derived from the fact that: 
Dionysus' most active worshippers yielded control of themselves to him and performed sexual acts or acts full of sexual symbolism. [Hence] Paul may contrast this behaviour with inspiration by God's spirit. (p. 550)

Keener (1993:550), however, is quick to point out that people might not always associate drunkenness with Dionysus, because 'drunkenness was more commonly associated with loss of self-control'. Loss of self-control certainly subsumes under the Greek asotia which is commonly translated into 'excess' (e.g. King James Version [KJV]). According to Clarke (in Studylight.org 2019), the word 'means profligacy and debauchery of every kind; such as are the general concomitants of drunkenness'. In contrast to these traits, in Ephesians 5:18, Paul insists on ' $t$ temperance and sobriety' (Edwards 2019).

In Romans 13:13, Paul enjoins Christians, 'Let us conduct ourselves becomingly as in the day, not in reveling and drunkenness, not in debauchery and licentiousness, not in quarreling and jealousy' (RSV). The Greek eusche mono-s is what is rendered 'becomingly' (or 'honestly', KJV). In view of the opening $h o^{-}$s en he-mera [as in the day], 'the word denotes here a walk of life the entire opposite of ... the things done in secret [or darkness] of which it is a shame to speak' (Benson Commentary in Bible Hub 2019b:online). It connotes decency exemplified in holiness, and not in vices such as those listed in this verse. It is important to note the juxtaposition of $\mathrm{ko}^{-}$mois and methais [reveling and drunkenness]. According to Pulpit Commentary (in Bible Hub 2019b), ko'mois 'derived from Comos, the god of feasting and revelling, that is feasting with lascivious songs, accompanied with music [all] ... acted in the night-time'. Bengel's Gnomen (in Bible Hub 2019b) affirms that $k^{-}$mos was 'a feasting, a lascivious banquet, with dancing and various disorderly acts'. Keener (1993:442) may therefore be correct when he opines that Paul's presentation here is typical of Jewish characterisation of 'gentile behaviour [which is often] in terms of wild drinking parties and premarital sex, activities [that] were done at night'. In this way, the apostle associates methais [drunkenness] with unholy nocturnal vices. In a way similarly to Romans 13:13, in 1 Corinthians 5:11, Paul groups drunkards with fornicators, idolaters, revilers and robbers, warning members of the Roman church not to keep company with such people. In 1 Corinthians 6:10 and Galatians 5:21, all such persons, including drunkards, will not inherit the kingdom of God.

In a couple of passages, Paul warns Christian leaders particularly against excessive use of wine. In 1 Timothy 3, one of the qualifications for the office of a bishop (v. 3; cf. Tt 1:7) and a deacon (v. 8) is that candidates must not be 'given to wine' (v. 3) or 'given to much wine' (v. 8; cf. Tt 2:3). In Titus 2:3, the same admonition is given concerning older women. Having used the word ne $e^{-}$phalios [temperate] for the older men in Titus 2:2 and ho $^{-}$sauto $^{-}$s [likewise] in verse 3, Paul must have given the same injunction concerning older men in verse 2 . The apparent problem with these qualifications as they relate to the use of wine, is the addition of the adjective polus [much] in verse 8 (cf. Tt 2:3) which is absent in verse 3. Paul seems to be saying bishops should not to be 'given to wine' while deacons must not to be 'given to much wine'. In view of the use of words in this way, some are of the view that 'Paul's instructions pertaining to the qualifications of elders and deacons have created misunderstanding regarding the use of alcoholic beverages' (Miller 2003). The Greek word rendered 'not given to wine' in verse 3 is paroinos, which is a combination of para [besides, with, at] and oinos [wine]. Hence, in Thayler's Greek Lexicon (in Koehler et al. 1994-2000) paroinos refers to 'one who sits long at his wine'. The UBS Lexicon renders it as 'given to strong drink' (in Koehler et al. 1994-2000), while Friberg Lexicon defines the word as 'addicted to wine, drunken' (in Koehler et al. 1994-2000). In view of these definitions, in 1 Timothy 3:3, Paul warns against excessive use of wine, in which case the verse is in harmony with verse 8 because of the phrase $m e^{-}$oino $^{-}$pollo- prosechontas [not given to much wine], which definitely indicates excess. Therefore, since it does not make sense to think that Paul intends different qualifications for the two offices, 1 Timothy 3:8 invariably helps to clarify the intent of verse 3 ; in both verses, the apostle is warning against excessive use of wine by bishops and deacons. This fact is buttressed in Titus 2:3 where a similar expression is used in warning older women against excessive drinking. Moreover, the interpretation that Paul warns against excess of wine in both of 1 Timothy 3:3 and 8, is in consonance with his general condemnation of drunkenness, as discussed above. Furthermore, the English translations do not reflect any semantic difference between Timothy 3:3 and 8 arising from the addition of polus in the latter verse. The New International Version (NIV) has 'not given to much wine' in verse 3, and 'not indulging in much wine' in verse 8 . The New American Standard Version (NASB) has 'not addicted to wine' in 1 Timothy 3:3, and 'not addicted to much wine' in verse 8 . The translator is not likely to intend a difference between 'addiction to wine' and 'addiction to much wine'. In fact, 'addiction to wine' already indicates too much of it; hence, 'addiction to much wine' is rather tautological. In its exposition on 1 Timothy 3:3, Bible Study Tools (2019) agrees with the view that there is no difference between the two verses when it says, ' $[I]$ t signifies one that is not given to much wine, as in (1 Tm 3:8) is not addicted to it, or a follower of it'. Bible Study Tools (2019) supports its view with the Syriac version which states that the verse refers to one 'who does not transgress over wine or go beyond due bounds in the use of it, who is not immoderate in it'. Commenting on $1 \mathrm{Tm}$ 3:8, Guthrie (1994:1299) also seems to be on a par with this view when he says that 'candidates for both offices must be those not indulging in much wine'. In the same vein, Edwards (2019) does not see a difference between 1 Timothy 3:3 and 8 when he states: 'A bishop and those holding honorable position in the church should not be addicted to wine.'

In 1 Timothy 5:23, Paul admonishes Timothy: 'No longer drink only water but use a little wine for the sake of your stomach and your frequent ailments' (RSV). Commenting on this verse, Keener (1993) opines that in NT times: 
$[M]$ ost people drank wine with their meals (albeit about two parts water to one part [of] wine, and not distilled to a higher than natural degree of fermentation). Timothy [must have] been abstaining [so] ... Paul tells him to go back to using it. (p. 619)

Stein (n.d.) affirms that in those days there were not many beverages that were safe to drink, whereas there was also the danger of drinking water alone, because the available water was not safe. There were several ways by which water could be made safe to drink, but 'the safest and easiest method ... was to mix it with wine'. Keener (1993:619) adds that ' $[w]$ ine was often helpful in settling stomachs and preventing dysentery, as it disinfected water'. However, what is more important for this discussion is that the advice to Timothy to use oino $^{-}$oligo $^{-}$[a little wine] for his ailments, is supportive of the argument that in 1 Timothy 3:3, 8 the apostle teaches against excessive drinking. This advice is relevant in that allowance for oino ${ }^{-}$oligo $^{-}$for the pastor is consistent with the forbidding of oino $^{-}$pollo- $[$much wine] in 1 Timothy 3:8.

Nevertheless, some interpreters believe that in those passages in which Paul refers to wine, rather than teaching against excessive drinking, he is, in fact, ordering total abstinence from wine. Contrary to the idea that Paul condemns drunkenness in Ephesians 5:18, as discussed earlier, Bacchiocchi (2001:161) believes that the text is teaching total abstinence. According to him, the text is saying that 'the infilling of the Holy Spirit precludes the drinking of alcoholic beverages [because] it is scarcely conceivable that a person "filled with the Spirit" would crave intoxicating wine'. In the same vein, commenting on Romans 13:13, Patton (n.d.) opines that Paul here enjoins his audience to abstain totally from drinking as they would do from rioting, quarreling, et cetera. As the apostle could not think of moderate forms of these other vices, he could not have thought of 'moderate drinking'. Hence, if one admits that Paul talks about 'moderate drinking', one must also admit that he is referring to 'moderate rioting'. Patton (n.d.:77) concludes: 'All agree that in these, total abstinence is the only safe and Christian course, and why not equally so in the matter of drunkenness?' Miller (2003) advances the same line of argument in respect of me $^{-}$oino $^{-}$pollo- prosechontas in 1 Timothy 3:8. His thesis is that if one says the word much here means that deacons may drink wine moderately, one should also think that 'moderate rioting' is appropriate when 'Peter noted that pagans do not understand why Christians do not engage in the "same excess of riot"' in 1 Peter 4:4.

Interpreters who advocate the total abstinence view, maintain that in 1 Timothy 3, Paul teaches that church leaders should abstain from wine altogether. According to Patton (n.d.):

[T] he Greek me paroinon in verse 3 literally means 'not at, by, near, or with wine' [which] looks considerably like total abstinence. [Hence] [ $w]$ e find in this passage no countenance for the moderate use of intoxicating wine, but the reverse, the obligation to abstain totally. (p. 91)

Similarly, Miller (2003) believes that $m e^{-}$paroinon 'is enjoining abstinence, and perhaps even the act of [not] situating oneself in the presence of people and places where the consumption of alcoholic beverages is occurring'. Considering the phrase, me $e^{-}$paroinon, Kerr (1968:21) also states that Timothy was not only to be abstinent, but 'was to withhold his presence and sanction from those places inimical to the sobriety of himself and others'. Bacchiocchi (2001:170) takes his premise from the terms ne phalion [temperate, sober] and so-phrona [selfcontrolled, sensible] in 1 Timothy 3:2 (cf. Tt 2:2). In his own interpretation, the first means 'abstinent' and the second 'of sound mind', or 'sober minded'. In view of 'the order of terms ... [ $t]$ he Christian overseer is to be "abstinent" - strictly sober in body, in order that he may be sober in mind'. Bacchiocchi (2001:170) compares this text with 1 Peter 4:7 where the writer admonishes his audience to 'keep sane and sober for your prayers' (RSV), which, according to him, also depicts a clear 'connection between sober-mindedness and physical abstinence'. Patton (n.d.) finds evidence in 1 Timothy 5:23:

[T] hat both Paul and Timothy understood that total abstinence was an essential qualification for the Christian pastor. [This is because] in strict accordance with the direction, 'not given to wine', ... [Timothy] was a total abstainer. (p. 91)

Patton views the recommendation to 'use a little wine' as exceptional and for a medical purpose. Kerr (1968:20) also recognises the passage as the 'only one instance where possibly [Paul] advises the use of an alcoholic beverage'. But Patton (n.d.:91), Kerr (1968:20) and Bacchiocchi (2001:162) opine that oinos in 1 Timothy 5:23 does not necessarily refer to alcohol, because, as already reiterated by them, the term 'could refer either to fermented or unfermented grape juice'. For this reason, 'we cannot decide, ex cathedra, that it was alcoholic wine that Paul recommended' (Patton, n.d.:91).

Thus, the view that Paul taught total abstinence from alcohol, is hinged on a restricted interpretation of the words methais [drunkenness] and paroinos [not given to wine], and a generic consideration of the meaning of oinos. As discussed above, scholars who hold this view, claim that, in Ephesians 5:18, even with the use of methais, Paul enjoins his readers to abstain totally from wine. However, it would be instructive to know how Paul's original audience would have understood him in their social context, and in view of his general use of the root methuo ${ }^{-}$. As Patton (n.d.:77) himself acknowledges in his writing on Romans 13:13, drunkenness was rampant in Rome; hence, 'Paul wisely exhorted the Christians there to avoid it'. Moreover, as earlier seen, the root methuo- may have derived from certain heathen practices associated with pagan gods, and drunkenness was associated with vices such as rioting, quarreling and sexual immorality. It is therefore most likely that Paul's audience would have understood his message as a warning that drunkenness could lead them into these kinds of unholy practices. It is in this way that they would have understood Paul's message on methusoi [drunkards] along with fornicators, idolaters, revilers and robbers not inheriting the kingdom of God (1 Cor 5:11; 6:10; Gl 5:21). Furthermore, as will be shown below in the expatiation on the meaning of oinos and how it was used in 
NT times, Paul's readers were no doubt in position to differentiate between moderate drinking and drunkenness. As earlier said, when read in light of $\mathrm{me}^{-}$oino $^{-}$pollo prosechontas [not given to much wine] in 1 Timothy 3:8, meparoinon in 1 Timothy 3:3 is a reference to excessive drinking, and not total abstinence. Hence, almost all translations have correctly rendered the verse as 'not given to wine', which is the same thing as 'not addicted to wine'. Also, as mentioned in the study, Paul's advice for Timothy to use oino ${ }^{-}$oligo $^{-}$ [a little wine] for his ailments, is supportive of the interpretation that 1 Timothy 3:3, 8 is an admonition against excessive drinking in that the allowance for oino oligo $^{-}$is consistent with the forbidding of oino $^{-}$pollo- ${ }^{-}$[much wine] in 3:8. Paul's attitude in not commanding abstinence from wine, is in consonance with the nature of oinos and the manner in which it was drunk in NT times. As seen in this study, at that time oinos referred to grape juice that was inevitably fermented, for which reason it was drastically watered down before it was drunk. Dilution was taken so seriously that drinking wine unmixed was considered a barbarian custom. Among the Jews specifically, wine that did not properly carry three parts of water to one part of wine, was not considered as wine. And they enjoyed the mixture of wine and water so much that some did not think it appropriate to drink them separately. In fact, sometimes wine was diluted and drunk as a substitute for plain drinking water, which might confirm the statement that ' $[w]$ ine was an extremely common drink, with few alternatives, in first-century Israel' (Mowczko 2009). In view of this manner of using wine, it becomes clear that no strict distinction between fermented and unfermented wine existed by the time of Paul; hence, he could not have commanded total abstinence from wine.

The summary of Paul's teaching on alcohol is that he never enjoined abstinence, but warned Christians to avoid drunkenness. It is in this perspective that this teaching is most relevant for contemporary Nigeria. In the section below, the article assesses the implications of Paul's teaching on alcohol for the church in Nigeria.

\section{Implications of Paul's teaching on alcohol for the church in Nigeria}

The first fact that is noteworthy here, is the significant difference which exists between alcoholic drinks of the 1st century CE and those of today (Lawrence 2010). While at that time alcohol referred simply to fermented grape juice, today it refers principally to distilled liquors with far higher intoxicating potency. Moreover, unlike in the NT times when wine was mostly drunk as a beverage for the sake of taste and refreshment, today alcohol is often taken purposely for its intoxicating effect, which explains the enormous spread of the habit of excessive drinking 'among the common people' (Edwards 2019). This scenario is very much true of the Nigerian context; hence, the first implication for the church in Nigeria is that there is the need to develop a response from the Christian perspective to the problem of drunkenness with its attendant social problems.
As earlier mentioned, Nigeria is not only a country with heavy alcohol consumption, it is equally one in which the substance is heavily abused. Alcohol abuse in Nigeria occurs in various ways. One of them is regular episodic heavy drinking, which usually takes place during 'ceremonies ... [when young men boast] of drinking six to eight bottles of beer in a single episode' (Nelson 2015:108). Heavy drinking of this nature also occurs on daily basis by some men who have formed the habit of getting drunk every evening. The social vices like rioting, quarreling, fighting and sexual immorality which Paul associated with drunkenness, manifest in various ways in contemporary Nigeria. Nelson (2015:106) identifies alcohol abuse as 'a contributory factor in a wide range of social problems, including anti-social behaviour, crime, violence, domestic violence, strained relationships, family breakdown, and child abuse and neglect'. In the higher institutions, cult clashes have been on the increase in which 'youths cruelly maim their rivals with dangerous weapons, [and] this has been linked to the fact that alcohol is hazardously used among Nigerian youths' (Dumbili 2013:27). It must be mentioned that numerous health hazards are equally associated with alcoholism in Nigeria. Although data on these are still inadequate, 'there is consensus in research findings that alcohol use disorders account for the highest proportion of people admitted for treatment for their substance use problems' (Obot 2007:520). Dumbili (2013) affirms that in Nigeria, 'road traffic accidents due to drunk-driving [have] continued to claim lives yearly' (p. 28).

Thus, alcoholism has created a challenge for the church in Nigeria to bring its witness to bear on the 'secular problems of ordinary human life' (Mangayi 2014:135). The church in Nigeria can respond to this challenge by developing a Bible-based theology on attitude to alcohol for the enlightenment of its members. As earlier seen, while a few denominations encourage moderate drinking, others forbid drinking alcohol altogether. Also, as earlier mentioned, most churches do not even have any clear-cut statement of faith on alcohol. Given the focus of Paul's teaching on drunkenness, a Bible-based theology on alcohol would be one which does not forbid drinking, but excess of it. Rather than commanding total abstinence, the church's theology on alcohol should place emphasis on the dangers involved in abuse. This programme should be built into the church's scheme of activities. It should reflect periodically in sermons; it should be incorporated into the activities of the various groups and societies, particularly the men's and youth fellowships; it should be reflected in catechism, bulletins, magazines and all the teaching manuals of the church; and it should be built into the curricula of the church's schools and colleges. The theology on alcohol should include devising methods of helping alcoholics regain sobriety. The general public has a negative attitude towards alcoholics and thereby making the alcoholic to feel that 'he or she is rejected and alone, and isolated from others' (DeJong 1985:55). To this end, the church has the responsibility to teach its members to have a caring attitude towards alcoholics in order to help them recover from the 
problem. Church members must be taught to 'avoid stigmatisation, destructive criticisms and gossips against alcoholics, but educate them with passion and love. This is the kind of attitude that [leads to] positive and progressive change' (Njoku 2012:72).

\section{Conclusion}

This article examined Paul's teaching on alcohol, assessing its implication for the church in Nigeria in relation to Christian attitude to alcohol consumption. The article found that the Greek word oinos in the NT refers to fermented grape juice that was normally watered down before drinking in order to reduce its alcohol content. From Paul's writings it appears that this substance was commonly abused in the general society; hence his warning to Christians generally and church leaders specifically not to be involved in that habit. However, it was discovered that, like other biblical authors, Paul did not command total abstinence from alcohol. The relevance for Nigerian Christians therefore resides in the context of widespread alcohol abuse. The article views this as a challenge to the church and suggests that it should come up with a Bible-based theology on alcohol, which enjoins Christians to shun excessive drinking.

\section{Acknowledgements Competing interest}

The author declares that no competing interest exists.

\section{Author(s) contributions}

I declare that I am the sole author of this research article.

\section{Ethical consideration}

This article followed all ethical standards for carrying out research without direct contact with human or animal subjects.

\section{Funding information}

This research received no specific grant from any funding agency in the public, commercial or not-for-profit sectors.

\section{Data availability statement}

Data sharing is not applicable to this article as no new data were created or analysed in this study.

\section{Disclaimer}

The views and opinions expressed in this article are those of the author and do not necessarily reflect the official policy or position of any affiliated agency of the author.

\section{References}

Adedipe, S., 2017, 'God bless Pastor Lazarus Muoka (4) - His alcohol ban', The Sun, 22 March 2017, viewed 18 October 2019, from https://www.sunnewsonline.com/ god-bless-pastor-lazarus-muoka-4-his-alcohol-ban/.
Akpu, P., 2016, 'Pastor Adeboye's position on Christians drinking alcohol', Newspeak, viewed 18 October 2019, from https://www.newspeakonline.com/read-pastoradeboyes-position-on-christians-drinking-alcohol/.

'Alcohol sales surge in Nigeria despite rising religious beliefs', 2012, Vanguard, 3 September 2012, viewed 27 August 2019, from https://www.vanguardngr. com/2012/09/alcohol-sales-surge-in-nigeria-despite-rising-religious-beliefs/.

Bacchiocchi, S., 2001, Wine in the Bible: A biblical study on the use of alcoholic beverages, Biblical Perspectives, Berrien Springs, MI.

Barnes, A., 1875, Notes on the New Testament, Luke-John, 2 vols., Amazon, London.

Bible Hub, 2019a, 'Commentary on Acts 2:13', Bible Hub, viewed 26 October 2019, from https://biblehub.com/commentaries/mhcw/acts/2.htm.

Bible Hub, 2019b, 'Commentary on Romans 13:13', Bible Hub, viewed 20 November 2019, from https://biblehub.com/commentaries/romans/13-13.htm.

Bible Study Tools, 2019, 'Commentary on 1 Timothy 3:3', Bible Study Tools, viewed 21 November 2019, from https://www.biblestudytools.com/commentaries/gillsexposition-of-the-bible/1-timothy-3-3.html.

Bonhoeffer, D., 1971, Letters and papers from prison, enl. edn., SCM, London.

Brown, K., 2015, 'The new wine of Acts 2:13', The brown Bible, viewed 26 October 2019, from https://brownbible.com/index.php/en-us/newsletter/general-bibletopics/75-the-new-wine-of-acts-2-13.

DeJong, A.C., 1985, Help and hope for the alcoholic, 3rd edn., Tyndale House, Wheaton, IL.

Dumbili, E., 2013, 'Changing patterns of alcohol consumption in Nigeria: An exploration of responsible factors and consequences', Medical sociology online 7(1), 20-33, viewed 28 August 2019, from www.medsoconline.org

Edwards, D.M., 2019, 'Drunkenness', in International Standard Bible Encyclopedia viewed 17 November 2019, from https://www.biblestudytools.com/encyclopedias/ isbe/drunkenness.html.

Ellis, J., 1883, The wine question in the light of the new dispensation, Amazon, New York, NY.

Geisler, N.L., 1982, 'A Christian perspective on wine-drinking', Bibliotheca Sacra 139 (553), 43-56.

Gentry, K.L., 1986, The Christian and alcoholic beverages, Amazon, Grand Rapids, MI.

Gordon, E., 1947, Christ, the apostles and wine: An exegetical study, Sunday School Times, Philadelphia, PA.

Guthrie, D., 1994, 'The pastoral letters', in D.A. Carson, G.J. Wenham, J.A. Motyer \& R.T. France (eds.), New Bible Commentary, pp. 1292-1315, IVP, Nottingham.

Helicopter View, 2017, 'Top-10 alcohol-drinking countries in Africa', Helicopter View, viewed 27 August 2019, from http://helicopter-view.com/blog/top-10-alcoholdrinking-countries-in-africa1.

Irekamba, C. \& Adunwoke, P., 2014, 'Nigeria: Should clerics touch money from breweries, alcoholic producers?' The Guardian, 30 November 2014, viewed 28 August 2019, from https://allafrica.com/stories/201412011367.html.

Keener, C.S., 1993, The IVP Bible background commentary: New Testament, InterVarsity, Grand Rapids, IL.

Kerr, E.A., 1968, Alcohol and the Scriptures, 2nd edn., Presbyterian Church of Victoria, Victoria.

Koehler, L., Baumgartner, W. \& Stamm, J.J., 1994-2000, Hebrew and Aramaic Lexicon of the Old Testament, trans. \& ed. under supervision of M.E.J. Richardson, 2003 ed., Koninklijke Brill, Leiden. (Bible Works 6).

Kou, C., 2015, 'The wedding of Cana: The bridegroom revealed (John 2:1-11)' Academia, viewed 30 October 2019, from https://www.academia.edu/27448189/ The_Wedding_of_Cana_The_Bridegroom_Revealed_John_2_1-11.

La Vista Church of Christ, 2016, 'Drinking in the New Testament', La Vista Church of Christ, viewed 25 October 2019, from http://lavistachurchofchrist.org/ LVSermons/DrinkingInTheNewTestament.htm.

Lawrence, B.J., 2010, 'The Bible says drunkenness is a sin (Galatians 5:21): But is occasional social drinking okay for Christians?', Christian Bible studies, viewed 17 November 2019, from https://www.christianitytoday.com/biblestudies/bibleanswers/personalconcerns/alittlewineforthesoul.html?start=2

Mangayi, L.C., 2014, 'Mobilising the local church for social justice and reconciliation: Theological/missiological reflections on the ministries of the Baptist Union of Southern Africa (1996-2011)', The South African Baptist Journal of Theology 23, Southern

Miller, D., 2003, 'Elders, deacons, Timothy, and wine, Apologetics Press, viewed 21 November 2019, from https://www.apologeticspress.org/apcontent.aspx?category= 11 \&article $=1208$

Mowczko, M., 2009, 'Water into wine - John 2:1-12', John Bible study notes, viewed 30 October 2019, from https://margmowczko.com/water-into-wine-john-2v1-12/.

Nelson, E.E., 2014, “"To drink or not to drink?": Moral ambiguity of alcohol in the Pentecostalist imagination', African Journal of Drug and Alcohol Studies 13(2), 118-129.

Nelson, E.E., 2015, 'Alcohol use, intimate partner violence and family well-being: A qualitative study in Oron, Nigeria', African Journal of Drug and Alcohol Studies 14(2), 105-113.

Njoku, E.U., 2012, 'A study of Proverbs 23:29-35 and the effects of alcoholism in Nigerian society: The role of the church', MA thesis, University of Nigeria, Nsukka.

Obot, I., 2007, 'Nigeria: Alcohol and society', Online Library 102(4), 519-522. https:// doi.org/10.1111/j.1360-0443.2006.01619.x 
Patton, W., n.d., 'Bible wines or the laws of fermentation and the wines of the ancients', Int'I college of the Bible, viewed 01 September 2019, from http://icotb. org/resources/Patton,William-BibleWines.pdf.

Pliny the Elder, 1960, The Natural History, vol. 14, no. 11, pp. 80-85, trans. by $\mathrm{H}$. Rackham, The Loeb Classical Library, Cambridge.

Pope, K., 2011, 'Ten reasons Christians should not drink alcohol', Olsen Park Church of Christ, viewed 18 October 2019, from http://www.olsenpark.com/Sermons11/ Alcohol.html.

Servant, D., 2019, 'Is it a sin to drink alcohol?' Heaven's Family, viewed 18 October 2019 from https://www.davidservant.com/is-it-a-sin-to-drink-alcohol/?motiv=H000-ADW S\&gclid=CjwKCAjwxaXtBRBbEiwAPqPxcMT42I_gjogSg42VmHIWggxjpjZOtvHka UYd80BQlioVeVLgZZXwuBoChrMQAvD_BwE.
Stein, R.H., n.d., 'Wine-drinking in New Testament times', Swartzentrover.com, viewed 17 November 2019, from http://www.swartzentrover.com/cotor/bible/Doctrines/ Holiness/Drugs\%20\&\%20Alcohol/Wine-Drinking\%20in \%20New\%20 Testament $\% 20$ Times.htm.

StudyLight.org, 2019, 'Commentary on Ephesians 5:18', StudyLight.org, viewed 20 November 2019, from https://www.studylight.org/commentary/ephesians/5-18. html.

Udodiong, I., 2018, 'Is it a sin for pastors and Christians to drink?', Pulse Nigeria, viewed 27 August 2019, from https://www.pulse.ng/communities/religion/ alcohol-is-it-a-sin-for-pastors-and-christians-to-drink/xqwteg0.

World Health Organisation (WHO), 2004, Global status report: Alcohol policy, WHO, Geneva. 